\title{
Bcl-2 Inhibitor S65487
}

National Cancer Institute

\section{Source}

National Cancer Institute. BCl-2 Inhibitor S65487. NCI Thesaurus. Code C158510.

An inhibitor of the anti-apoptotic protein B-cell lymphoma 2 (Bcl-2), with potential proapoptotic and antineoplastic activities. Upon intravenous administration, $\mathrm{BCl}-2$ inhibitor S65487 binds to and inhibits the activity of $\mathrm{Bcl}-2$, thereby restoring apoptotic processes in tumor cells. $\mathrm{Bcl}-2$ protein is overexpressed in many cancer types and plays an important role in the negative regulation of apoptosis; its expression is associated with increased drug resistance and tumor cell survival. 